DOI: 10.20472/IAC.2017.032.030

\author{
BABULIA MGHEBRISHVILI \\ Ivane Javakhishvili Tbilisi State University, Georgia
}

\title{
DEVELOPMENT OF MANAGERIAL AND MARKETING THINKING IN GEORGIA
}

\begin{abstract}
:
Commencement of the process of creation of the scientific theory of management and marketing, at the turn of the 19th and 20th centuries was the logical continuation of the practical experience gained by the mankind in this area. This process was initiated in the USA, though managerial and marketing thinking and practices were characteristic of almost all countries. This is natural as effective performance of entrepreneurial activities is possible only in case of proper management and orientation to the consumer needs. In this respect, Georgia is not exclusion. Georgian noblemen, merchants, craftsmen and peasants used to apply managerial approaches in their businesses and they also took into consideration the consumers' needs. In our opinion, the hired stewards, i.e. the "managers" administered the households of the noblemen. The leaders of the shops of merchants and craftsmen and their deputies were the managers as well. When selecting the managers the attention was paid to their organization skills, smartness, required for achievement of the goals set by the members of the shop. The noblemen and the peasants used to buy the consumer goods from the proceeds gained as a result of sale of the excessive agricultural products or exchanged them for the required commodities. The leaders of merchants and craftsmen performed their activities based on the consumers' requirements. In many cases the craftsmen produced the goods ordered by the consumers. In our opinion, only managerial and marketing thinking can explain the fact that the Georgians have created numerous varieties of the agricultural crops from the ancient period up to present. For example, currently, in small Georgia that has permanently resisted the enemies' attacks, there are recorded about 500 strains of grapes, up to 200 strains of apples, over 150 strains and forms of wheat. With this approach, Georgian farmers met different demands of the consumers on one hand and on the other - distributed the risks and prevented expected losses.
\end{abstract}

\section{Keywords:}

management, marketing, scientific theory, thinking, requirements.

JEL Classification: M31 


\section{Introduction}

Management and marketing, as the scientific disciplines appeared in the USA. But the elements of managerial and marketing thinking can be seen in economic considerations in all countries. This is natural, as without proper management of any activities and their orientation towards the consumer no positive outcomes could be obtained in a long run. Georgia is not exclusion as well, with respect of development of the management and marketing thinking. Naturally, from the ancient time up to present, Georgian economic thinking includes management and marketing elements though, currently, it is not properly studied. This fact caused our interest in this issue and conducting of the research.

\section{Results of research}

For many centuries Georgian noblemen, peasants, craftsmen and merchants applied management methods in their activities and approached to their work process in marketoriented, i.e. consumer-oriented way. Though, in that period, most organizations were small and mostly managerial and non-managerial work were not divided. One could say that management and marketing practice, similar o the other counties, existed in the ancient time. But understanding and implementation of their idea, objectives and methods are new for the country. Unlike many other countries, understanding of the scientific ideas of management and marketing is related not with the turn of $19^{\text {th }}$ and $20^{\text {th }}$ centuries but with decomposition of the Soviet Union and gaining of independence (90s of the $20^{\text {th }}$ century). But this does not mean that certain elements were not used in Soviet Georgia.

Development of agriculture in Georgia included elements of managerial and marketoriented approach as confirmed by the historical sources dealing with agricultural development. First, the noblemen managed their economies through the stewards. In our opinion, "Georgian stewards were "hired managers" that provided management of the noblemen household economies. Second, while for centuries small Georgia was permanently engaged in defending against attacks of numerous enemies, there are recorded over 500 vine varieties, about 200 apple and over 150 wheat varieties and forms [Technologies of apple growing (2014); Adeishvili K. (2012); Chichua D. (2017)]. Versatility of the varieties of these three plants, on one hand, demonstrates that in Georgia, the farmers duly regarded the consumers' different requirements and on the other - they were able to think in "managerial" manner and prevent expected risks and losses. Though, the farmers knew nothing about marketing or risks management theories.

Agriculture development in Georgia has taken place through gradual accumulation and expansion of knowledge and experience. Say, viticulture and winemaking: Naturalclimatic conditions provide the best environment for development of high quality viticulture and winemaking in Georgia. Due to drastic differences in viticulture and winemaking, our 
territory is divided into two parts: Eastern and Western Georgia, including six regions: Kakheti, Kartli, Meskheti, Imereti, Racha-Lechkhumi and Black Sea Coastal zone...Among these regions, Kakheti Region is at leading position [Keshelashvili G.(2016)]. Naturally, for development of viticulture and winemaking "... requires certain knowledge and great foresight talent to deal with this hard work [Kamarauli S., Andghuladze R., Burkadze V., p.245 (2005)]. Georgian farmers managed to do this for many centuries, thanks to their foresight and taking into consideration of the consumers' requirements. And foresight is nothing else that Georgian farmers' prospective thinking. As for the requirements, they comprise the motif that made them create the new varieties and import the foreign ones. The same could be said about the wheat as well. Similar to vine, the history of wheat commenced in the ancient time, in the territory of our country. Georgia is located in the area of origin of the wild wheat. This plant was spread in our territory as early as in the Neolithic and Chalcolithic ages. As widely known, the varieties that are very close to the wild wheat by evolution, are maintained up to present only in Georgia" [Adeishvili K. (2012)]. History of apples is very long in Georgia as well. It was cultivated in Georgia about four thousand years ago [Apple growing technology (2014)] and there are numerous varieties in the country now.

Georgian farmers have been creating new varieties of the vine, wheat and apples to achieve frost resistance, heat resistance, resistance to various diseases, high yields, stable yields etc. Thus they attempted to distribute the risks and prevent unexpected dangers and losses caused. For example, Rkatsiteli grapes, widespread in Georgia, are resistant to the frost, GoruliMtsvane is resistant to the diseases, Aladasturi resists well the fungi, Ojaleshi is well protected against rot and mildew. Following grape varieties are distinguished with high yields: Aleksandruli, Budeshuri, Tavkveri black, Tsitska white, Mtsvane and others. Some of the listed grape varieties are spread in one region of Georgia, some - in the several ones [Mghebrishvili B., p.136 (2009)].

Wide variety of the grapes in Georgia were not created for risks prevention only, width of their range is caused by consumer oriented approach as well. Most of the grapes are intended for wine production but there are also table grape varieties, those, intended for making raisins, jams, churchkhelas. Based on the analysis of historical development of Georgian vine growing and winemaking, IvaneJavakhishvili mentioned that in Georgia "... there are 45 table varieties, 4 for the raisins, 1 for jam and 6 - for the pickles, and among the varieties intended for winemaking, 5 are good for young wine, 76 - for wine, 5 - for pelamushi and churchkhelas" [Javakhishvili I., p.606 (1986)].

Unique qualities of Georgian wheat varieties ensure risks prevention. For example, Makha is less sensitive to the soils. It grows well in the conditions of limestone, pebbles and high humidity. Sanduri is distinguished with resistance to draughts and frosts. In addition, it grows on all types of soil. Dika is distinguished with high yields and heat resistance. It does not require diseases' prevention measures. "DolisPuri" resists well the 
fungi and grows on very poor soils. Tavtukhi is resistant to the fungi as well [Gotsadze N. (2017)].

As mentioned above, development of crafts is directly linked with the managerial and market-oriented thinking and relevant practical activities. Historical sources confirm that the Georgians were engaged in the crafts from the ancient time. Various crafts have developed according to the existing requirements and this could not be done without proper management. Historical sources show that various craftsmen lived in Georgia from the ancient times, including goldsmiths, icon makers, masons, painters, wood-carvers, chandelier-makers, church plate makers, candle-makers, braziers, weavers, silk weavers, dyers, embroiderers, tailors, fur-dressers, felt-makers, saddle-makers, bricklayers, carpenters, joiners, sawyers, smiths, potters, turners, glass-makers, brushmakers, bowl-makers, pack-saddle makers, lamp-lighters, tambourine players, tariplayers, coppersmiths, butchers, bakers, tarrers, barbers, saddle-makers, fishers, millers, wine-suppliers, wheat-suppliers, cotton-suppliers, cordwainers, belt-makers, leatherdressers, soap-makers, brick-makers, tile-makers, stone carvers, locksmiths, confectioners, dressers and other small traders" [Chichinadze Z., p.15-16 (1900)]. Naturally, unless the demand for the products of the above listed craftsmen, they would not exist. These were the demands that caused emergence and further development of various crafts in Georgia.

In late feudal age, in Georgia, the craftsmen and merchants created the professional associations, the guilds. "Business was the basis of craft organizations and thus, the producers or traders of various goods used to create separate organizations (guilds) [Meskhia Sh., p. 141 (1949)]. They “... were the successors of the similar associations of the previous period"... in $17^{\text {th }}-18^{\text {th }}$ centuries they became better established. The internal structures of the guilds have developed and their administration have finally formed" [Kutsia K., p.5 (1984)]. And this means that the guild was administered according to the management principles.

As mentioned above, the professional associations of the craftsmen and merchants have existed in Georgia in earlier period. As early as in the $8^{\text {th }}$ century, in the country there was used the term "urtali" with the meaning of "joint activities", "joint business", "union of merchants" widespread in the countries conquered by Mongols to denote the companies consisting of the large merchants" [Kutsia K., p.9 (1984)]. The term guild, in a form of "Hamkari" appeared in the second half of $18^{\text {th }}$ century [Kutsia K., p.10 (1984)]. The guilds were administered by the "Ustabashs" - the managers. One of the main duties of the Ustabashs was putting into order the activities of the craftsmen and merchants"... their obligations included also distribution of the raw materials between the masters" [Kutsia K., p.96-97 (1984)]. Thus, the Ustabashi made decisions on such significant issues as resources distribution, opening of the new shops, implying making contacts with various organizations and people, negotiations in the name of the guild etc. The Ustabashi was 
able to make decisions only through the relations with his staff and collection of information from them. Thus, the Ustabashi performed the manager's main roles in the guild, including interpersonal relations, information, decision-making.

Ustabashi had to perform his activities according to the guild's charter. In some cases the charters had different names. E.g. "Pedlars' Book of Conditions". This brief "Book of Conditions" set the main economic interests of the pedlars' guild: nine of twelve sections dealt with the unity of the economic interests of the guild members... here are also briefly regarded the duties and remuneration of some servants (Ustabashi, Igitbashi), general duties and obligations of the guild members etc [Meskhia sh., p.148 (1949)]. The mentioned document shows that the obligation of Ustabashi (master) was making contacts with the partners and procurement of the goods. Other members of the guild agreed with the Ustabashi's decision [Charter, p.138-139 (1800)].

Members of the guild were accountable to the guild Ustabashi and they obeyed to him. This can be seen from the charter of Kutaisi bread bakers' charter. Second article of this document states the following: "These three elected persons shall manage the business in the guild in good faith and according to the law - as relevant and we, the guild, shall not contradict to them" [Charter, p.139 (1871)].

Charter of the guild paid great attention to production of the high quality goods. "... the Book of Blessing of the Akhaltsikhe Shoemaker-Craftsmen: states: "our duty is to punish the master for low quality products..." [Kutsia K., p.23 (1984)]. Naturally, the shoemakercraftsmen of Akhaltsikhe did not know what marketing was but they were well aware that the consumers would not buy the low quality products and they would suffer losses. Thus, the guild followed its own interests by production and sale of the proper quality goods and thus took care about the consumers as well. Care about the consumers was of contradictive nature. 'We think that in spite of its contradictory nature marketing ethics [Mghebrishvili B., p.42 (2014)] plaid significant role in the process of the guild development. Regarding this, they adjusted their products to the consumers' requirements, i.e., primarily, they used their goods to influence the consumers.

Charter of the Goldsmiths provides interesting materials, with respect of managerial and market-oriented thinking. Article three of the charter states that "the guild members shall recognize the head of their craft and three other advisors as the leaders in their craft and they shall follow and obey all their lawful requirements... and they (the leaders) shall, according to their oath, shall manage [the guild] with dedication, in good faith and honestly and protect their (the craftsmen's) rights" [Kutsia K. Annex 4, p.149 (1984)]. Thus, the rights and obligations in the guild were determined by the charter and they were binding.

The guilds played great attention to professionalism, being well aware that only professional members could produce the goods of proper quality. According to the Goldsmiths' Charter, the elected heads and generally, the guild, primarily should care 
about mastering of the students. Article five of the mentioned Charter states that "no student that has not sufficiently mastered in his craft shall be blessed [as a master]. Unless in the presence of four leaders and masters of the guild he shows that he is properly skillful, the student shall not be blessed as an independent master" [Kutsia K. Annex 4, p.150 (1984)]. Naturally, inclusion of such article into the charter was dictated by the need of production of high quality goods and this could be achieved by the guild only with the skillful masters. This contributed to the image of the guild, ensuring maintaining of the existing consumers and attraction of the new ones. Article of the charter providing punishment of the masters in case of deception of the customers served to maintaining of the existing customers and attraction of new ones as well. Goldsmiths' Charter provided also social protection of its members. Section c), article seventeen stated that "if any of the guild members falls ill due to his age or any misfortune and he is not able to work and he has no supporter and any subsistence, especially, if he has young children, in hard time of winter, on the Christmas day, in the period of Lent, on the Easter day, assistance shall be provided him from the treasury, including: bread, firewood, coal, cash by the decision of four [leaders] and eight elected [persons]... if required, the guild treasury shall serve with dedication to the guild, the elders and young, the poor and rich. For example, if in any house the death comes, the house is ruined or something similar [occurs] or if [someone] is so badly ill that he needs the doctor etc." [Kutsia K. Annex 4, p.154-155 (1984)].

Thus, the guilds of the late feudal period, together with the consumers' rights, protected the interests of their members. And this means that the guilds used the elements of internal marketing as well. The guild leaders understood that if the consumers did not like the produced goods they would lose the clients. To avoid this, it was necessary that the guild members were satisfied and protected. Only in such case they would be able to produce high quality goods. The customers would be lost if they were deceived as well and therefore, the guilds paid attention to the control function as well. I.e. the actual situation dictated the guild leadership to think in managerial and market-oriented thinking.

Actions performed by various enterprises and organizations for their products' promotion points to further development of the marketing way of thinking. These were primarily the advertisements published through press [Apil, A. R., Kaynak, E., and Todua, N., p. 531 (2009)].

Getting familiarized with the historical sources shows that in Georgia of $19^{\text {th }}$ century advertising of goods played significant role for the customers' stimulation. For promotion of their goods at market the manufacturers and dealers used printed advertising and outdoor advertising. Georgian newspapers of that period published various advertisements. "In 1861, in Tbilisi an agricultural newspaper "GutnisDeda" published the first advertisement... In that period, in Tbilisi, there were very popular the advertising boards of Laghidze posted in his shops - "If you want to be a beautiful woman, you should 
have Laghidze lemonade" [History of Georgian Newspaper Advertising (2017)]. In that period the advertisements were extensively published by the newspapers "Droeba" and "TsnobisPurtseli". For example, in 1884, $6^{\text {th }}$ issue of newspaper "Droeba" published such advertisement of the "English Shop" operating in Tbilisi: "Hair growth preparation, makes the hair stronger and returns original color to it, price of per flask -2 rubles; with delivery - 2 rubles and 28 kopecks" [History of Georgian Newspaper Advertising (2017)]. These advertisements clearly show that in Georgia of $19^{\text {th }}$ century their authors were well aware in this sphere. The attention is focused on the benefits that could be gained by the buyers if they bought the products. Contents of the advertisements show that they were of both, informative and convincing nature. The advertisements of that period it becomes clear also that the retailers of that period used to offer additional services. If required, they offered to deliver the products to the clients. This is clear from the advertisements, as well as from the other sources.

In marketing respect, the following information intended for the customers is of significance - "for the attention of those resting in Kojori the following announcement was published: wines in the Sololaki wine warehouse are delivered to Kojori every Saturday at the city prices. Delivery is possible as well. Delivery is free. Price per bottle of Kakhetian wine is from 15 kopecks to 1 ruble. Sale with the buckets will be provided at discounted prices. Please, specify accurate address. You can also order the coach to Kojori and Mangisi. Price of tickets is 1 ruble and 20 kopecks for the front sites and 1 ruble for the back sites" [Kalandadze B., p.16 (2008)]. This announcement shows that to stimulate the buyers the manufacturers applied various techniques: offering of the products at low prices, delivery for free, discounts in case of purchasing of large quantities, different prices for different places. Thus, to achieve their goals, the entrepreneurs used various pricing strategies: pricing with discounts; pricing for sales stimulation; pricing intended for different locations. Thus, in $19^{\text {th }}$ century, in Georgia, the merchants had marketing thinking and used the marketing techniques in their activities.

In $19^{\text {th }}$ century, Georgian entrepreneurs have not forgotten to award the permanent clients. This can be clearly seen from the following announcement published in press: "In Tbilisi, head office of $Z$. Sarajishvili sells only Kakhetian wine. Prices: from 25 kopecks to 1 ruble per bottle and from 4 rubles per bucket. Real and permanent buyers can buy the wine with discount. The enterprise will deliver the wine to those who order more than 10 bottles..." [Kalanndadze B., p.18 (2008)].

To stimulate their customers the entrepreneurs in Georgia used the souvenirs as well. For example, M. Onanov, who has built the wine factory in 1908 in Vartsikhe and in 1915 - in Zestaponi, to improve the image of his products, ",,, used to put into the boxes of Champaign and cognac valuable gifts (watch, cigar case) with his signature" [Stepanishvili S., p.23 (1967)]. In this case the object of stimulation is the customer and 
the means of stimulation - the gift. Thus, in Georgia, the entrepreneurs used to apply sales stimulation techniques as required.

In $19^{\text {th }}$ century, in Georgia, the entrepreneurs used to stimulate not only the individual customers but the business clients as well. For this purpose they participated in the commercial exhibitions and contests. This was the best means for establishing the products at market. In this respect, there are numerous examples in the history of Georgian wine and alcohol beverages' companies. For example, "in 1894, in St, Petersburg, at international exhibition of wine and vine, the vine saplings grown in Sakara viticulture herbarium were awarded the silver medal. In the category of wines the following awards were granted: great golden medal to the Emperor's Tsinandali Prince estate; great silver medal to Prince Andronikashvili... In 1895, in Bordeaux, at international exhibition, in the category of wines, the silver medal was awarded to the winemakers of Tbilisi Dickenson and Pridonashvili [Kalandadze B., p.348 (2008)]. Among winemakers of $19^{\text {th }}$ century Prince $Z$. A. Jorjadze was the most well known producer. He established the firm "Prince Z. Jorjadze and K". Prince ZakariaJorjadze "sent from his wine cellar the wines to international exhibitions in Moscow and Odessa where he was granted high awards and in 1889, at Paris World Exhibition, Jorjadze's wines were awarded the Grant Prix... Jorjadze has presented both Kakhetian table and liquor-type wines"... Prince I.K. Bagration-Mukhraneli was an outstanding person as well. In 1882, at Moscow international exhibition, for the best wines, Prince Bagration-Mukhraneli was awarded the highest award - the state emblem. In 1886, at Paris exhibition, his wines were awarded grand prix and in 1905, Prince's wines and Champaign gained golden medals in Moscow Agricultural Exhibition and Paris Hygiene Exhibition" [Kalandadze B., p.350 (2008)]. D.Z. Sarajishvili's company actively participated in the exhibitions. The mentioned company and personally David was granted the following awards: 1889, Tbilisi - Caucasus Agriculture and Industry Exhibition: golden medal; 1889, Paris, World Exhibition - two silver medals; 1893, Chicago, Columbia Exhibition - bronze medal..." [Kalandadze B., p.353 (2008)]. Various awards of Georgian winemakers clearly demonstrate that Georgia produced high quality wines. Thus, the winemakers primarily paid attention to the wine quality. They knew that the main factor stimulating the customer to buy is the product as such, with its characteristics. Winemakers paid due attention to the product's image as well and fought to create and maintain the image of Georgia as a wine producing country. For these considerations they participated in international exhibitions.

Famous scientists, P. Kotler, in his book "Marketing Insights from A to Z: 80 Concepts Every Manager Needs to Know" emphasizes such significant conception of marketing as sponsorship [Kotler Ph., p.170 (2016)]. Companies actively seek the ways to become well known to the wide society and for this purpose they applyadvertisingand sponsorship. Naturally, sometimes advertising and sponsorship is related to the costs only but it can provide great benefits to the companies. Some Georgian entrepreneurs extensively used 
advertising and sponsorship to gain positive image [Todua N., p.64 (2012)]. Though, sponsorship of the others, in many cases, was simple charity. Activities of famous Georgian entrepreneur, David Sarajishvili provide clear example of this. One could say that "in Georgia, there was no any sphere of society's life, including education, art and history that have not received assistance from David Sarajishvili. He generously granted funds for Georgian theatre, literacy society, artists, talented young people so that they were able to benefit their nation and country" [Gujejiani G., p. 166 (1996)].

\section{Conclusion}

Development of Georgian economy, from the early period to present, could not and take place without managerial and market-oriented thinking as confirmed by the literary and historical sources of various periods. These issues have not studied in Georgian economic science, with few exceptions. This can be explained by the fact that Georgia was one of the soviet republics whose economy was riled without any managerial and market-oriented approaches. Hence, these two terms were not used either in the science or in practice. Though, this does not mean that certain elements of management and marketing were not used in practice. Now, when Georgia has gained independence and adopted market economy, management and marketing can play significant role in development of business. Regarding all these, we regarded that it would be significant to study development of marketing and management in Georgia and present the obtained results to the scientists and practitioners.

Our studies allowed us to make the following conclusions:

$\checkmark \quad$ In Georgian agriculture, wide range of Georgian varieties and foreign species was provided, on one hand, to prevent the expected risks and on the other - to meet the consumers' demands. I.e. for many centuries, Georgian farmers engaged in agriculture, used to think in managerial manner and used market-oriented approach.

$\checkmark$ Stewards of the noblemen, actually, were the hired managers.

$\checkmark$ The heads of the merchants and craftsmen guilds were the managers as confirmed by their obligations vested in them by their charters.

$\checkmark$ In Georgia of late feudal age, the fact that the charters of the guilds emphasized such issue as production of high quality goods, care about the professionalism of the guild members, punishment of craftsmen in case of deception of the clients, focus on the social issues, demonstrates that Georgian entrepreneurs used to think in market-oriented manner.

$\checkmark$ Existence and development of the market-oriented thinking, in the past centuries, in Georgia, can be evidenced by the history of advertising development. In $19^{\text {th }}$ century, inn Georgia, there was used both, the printed and outdoor advertising. 
The advertisements were built according to the key advertising principles, i.e. with the emphasis of the benefits gained by the clients through purchase of the product.

$\checkmark$ Advertisements and announcements published by press show that Georgian businessmen actively used the price adjustment strategies to promote their goods at market.

$\checkmark$ To stimulate the customers, Georgian entrepreneurs, traders and craftsmen actively used the means of sales' stimulation, such as the souvenirs.

$\checkmark$ Georgian entrepreneurs of $19^{\text {th }}$ century took care about the image of their own companies but the one of their country as well. For this purpose they actively participated in the international exhibitions and contests, as clearly evidenced by the history of development of the wine and alcohol producing companies. Some of them aid great attention to sponsorship that frequently was in a form of charity.

\section{References}

Abuashvhili I. (2017). History of Georgian newspaper advertisements. http://www.resonancedaily.com/index.php?id rub=5\&id artc=34294

Adeishvili K. (2012) Zanduri, Ipkli, Tavtukhi and the history of Georgian wheat. http://www.vinoge.com/samzareulo/zanduri-ifali-TavTuxi-da-garTuli-xorblis-istoria

Apil A. R., Kaynak E., and Todua N. (2009). Product Preference Differences of High and Low Ethnocentric Consumers in Georgia. In Proceedings of the 18th World Business Congress "Management Challenges in an Environment of Increasing Regional and Global Concerns". International Management Development Association, pp. 531-539.

Book of Conditions of the Peddlers (1800). Kutsia K. (1984). Guilds in Georgian Cities of $17^{\text {th }}-18^{\text {th }}$ centuries, Annex 1. Tbilisi.

Charter of Kutaisi Bakers Guild (1871). Kutsia K. (1984). Guilds in Georgian Cities of $17^{\text {th }}-18^{\text {th }}$ centuries, Annex 2. Tbilisi.

Charter of the Master Goldsmiths. Kutsia K. (1984). Guilds in Georgian Cities of $17^{\text {th }}-18^{\text {th }}$ centuries, Annex 4. Tbilisi.

Chichinadze Z. (1900). Georgian craftsmen and crafts in Georgia. Tbilisi.

Gotsadze N. (2017). Georgian wheat and Georgia - one of the ancient centers of origin of the wheat. https://sputnik-georgia.com/nature/20170509/235914766/qartuli-xorbali.html

Gujejiani G. (1996). David Sarajishvili's Charity Society. Tbilisi.

http://www.vinoge.com/degustacia/daviT-CiCuas-leqcia-Rvinis-klubSi-iSviaTi-vazis-iiSebisperspeqtivebi(2017)

Javakhishvili I. (1986). Works in 12 volumes. Volume V. Tbilisi 
Kalandadze B. (2008). Chronicles of Georgian Wine and Alcohol Beverages, Tbilisi.

Kamarauli S., Andghuladze R. Burkadze V. et al (2005). Production organization and management in the farm economies. Tbilisi.

Keshelashvili G. (2016). General Strategies of Georgian Winemaking Companies' Management in the Conditions of Integrated Development, Proceedings of the 23rd International Academic Conference, Venice, International Institute of Social and Economic Sciences. http://www.iises.net/proceedings/23rd-international-academic-conference-venice/table-of-content

Kotler Ph. (2016). Marketing Insights from A to Z 80 Concepts Every Manager Needs To Know. Translation from English to Russian

Kutsia K. (1884). Guilds in Georgian Cities of $17^{\text {th }}-18^{\text {th }}$ centuries. Tbilisi.

Meskhia Sh. (1949). From the history of the guilds organization. Works of the Institute of Economics, v. 3. Tbilisi, pp.141-153.

Mghebrishvili B. (2009). Elements of managerial and marketing approach in development of Georgian vitivulture and winemaking. Magazine Economy and Business. Tbilisi, pp. 134-138.

Mghebrishvili B. (2014). The ethics and retail management Collection of Materials of II International Scientific-Practical Conference. Kiev, 42-44.

Nozadze N. (2011). Unique nature and potential of Georgian wheat. http://agro.ge/index.php?m=1334

Stepanishvili A. (1967). Development of winemaking in soviet Georgia. Tbilisi.

Technology of apple growing. http://agrosc.ge/uploads/vashli axali(1).pdf

Todua N. (2012). Georgian consumers trust emotional advertising campaigns more than those based on logic. Tsu Science, Vol. 2, pp. 64-67. 